JIEB (ISSN : 2442-4560) available online at : ejournal.stiepancasetia.ac.id

\title{
PENGARUH MOTIVASI, INSENTIF DAN PROMOSI JABATAN TERHADAP PRODUKTIVITAS KERJA KARYAWAN PADA BAGIAN PENJUALAN PT KAPUAS TRIO TIRTA SARI MOTOR DI KUALA KAPUAS
}

\author{
Anita \\ Mahasiswa Sekolah Tinggi Ilmu Ekonomi Pancasetia Banjarmasin \\ Jl. A Yani Km. 5,5 Banjarmasin, Kalimantan Selatan \\ e-mail: anita11@yahoo.co.id
}

\begin{abstract}
This study aims to find out whether the motivation, incentives and promotion positions have significant effects on employee productivity on the sales department of PT Kapuas Trio Tirta Sari Motor in Kuala Kapuas. The research population numbers are 17 people. The data collection technique are questionnaire, documentation and observation. The data analysis model is multiple regression analysis. The research results show: (1) Simultaneously, motivation, incentive and promotion positions have a significant effect on employee work productivity. (2) partially, the variable of motivation, incentive, and promotion variable have no significant effect on employee work productivity.
\end{abstract}

\section{Keywords: motivation, incentive, job promotion, work productivity}

\begin{abstract}
Abstrak: Penelitian ini bertujuan untuk mengetahui apakah motivasi, insentif dan promosi jabatan berpengaruh signifikan terhadap produktivitas kerja karyawan pada bagian penjualan PT Kapuas Trio Tirta Sari Motor di Kuala Kapuas. Populasi penelitian berjumlah 17 orang. Teknik pengumpulan data melalui angket, dokumentasi dan observasi dan instrumen. Model analisis data yang digunakan regresi berganda Hasil penelitian menunjukan: (1) Secara simultan motivasi, insentif dan promosi jabatan berpengaruh signifikan terhadap produktivitas kerja karyawan dan (2) secara parsial variabel motivasi, insentif, dan promosi jabatan tidak berpengaruh signifikan terhadap produktivitas kerja karyawan.
\end{abstract}

Kata Kunci: motivasi, insentif, promosi jabatan, produktivitas kerja

\section{Latar Belakang}

Berbicara masalah motivasi bukanlah berbicara masalah yang mudah untuk segera dipecahkan. Akan tetapi, yang jelas adalah bahwa dengan motivasi yang tepat, para karyawan terdorong untuk berbuat semaksimal rnungkin dalam melaksanakan tugasnya karena mereka meyakini bahwa keberhasilan suatu organsiasi dalam mencapai tujuan dan berbagai sasarannya, kepentingan-kepentingan pribadi karyawan juga akan tercapai.

Daya perangsang atau daya pendorong yang mendorong karyawan untuk mau bekerja dengan segiat-giatnya antara karyawan yang satu dengan yang lain. Perbedaan ini disebabkan oleh perbedaan motif tujuan dan kebutuhan dan masing-masing karyawan un- tuk bekerja juga oleh karena perbedaan waktu dan tempat. Oleh karena itu, dalam memberikan motivasi kepada karyarwan haruslah diselidiki daya perangsang mana yang lebih ampuh untuk diterapkan dan lebih ditekankan Masalah produktivitas sangat erat kaitannya dengan masalah karyawan. Tinggi rendahnya produktivitas kerja karyawan dapat diukur dengan melihat sejauh mana karyawan dapat menyelesaikan suatu pekerjaan yang dibebankan kepadanya, apakah dia bisa menghasikan sejumlah produk dengan kualitas yang baik sesuai dengan waktu yang ditentukan dan tepat sasaran atau malah justru sebaliknya. Apabila karyawan telah dapat menyelesaikan pekerjaan sesuai dengan ha- 
rapan perusahaan sebagaimana ukuran diatas maka karyawan dianggap telah produktif.

Produktivitas kerja merupakan sesuatu yang kompleks dan senantiasa perlu ditingkatkan baik dari sisi individual maupun kelompok. Hal ini dikarenakan produktivitas merupakan tantangan yang harus dihadapi oleh semua komponen serta unsur organisasi dan merupakan urusan semua orang dalam organisasi kerja sehingga mereka mampu mengatasi berbagai macam situasi. Aksioma ini berlaku tidak hanya pada organisasi yang bergerak di bidang ekonomi, melainkan pula bidang organisasi lain seperti kenegaraan, politik nirlaba, bisnis, sosial budaya lembaga sosial masyarakat dan keagamaan (Siagian, 2002)

Produktivitas pada organisasi terdiri atas komponen tehnologi, modal dan sumber daya manusia. Sumber daya yang diberdayakan secara efesien merupakan salah satu faktor yang mampu menggerakan produkitivitas meskipun di lain pihak sumber daya manusia merupakan pemicu terjadinva pemborosan dan netisien dalam berbagai bentuk. Hal ini tercermin bila manajemen organisasi tidak mampu memuaskan kebijaksanaan pengelolaan sumber daya manusia dalam organisasi dan menjalankan praktek-praktek manajemen sumber dalam manusia. Pengaruh sumber daya manusia pada produltivitas kerja dapat terlihat pada hasil pekerjaannya. Tingkat absensi, kecelakaan, intensi keluar dan kontribusinya pada perusahaan. Oleh sebab itu, pengembangan sumber daya manusia untuk meningkatkan produktivitas dan motivasi perlu diperhatikan dan menjadi skala prioritas.

Produktivitas kerja tidak terlepas dari efisiensi dan efektivitas. Efesiensi menekankan pada hasil kerja, sedangkan efektivitas berhubungan dengan proses pencapaian tujuan yang dikaitkan dengan kerja manusia atau peningkatan tenaga kerja manusia, pembaharuan hidup dan kultural, sikap mental memuliakan kerja serta perluasan upaya untuk meningkatkan mutu kehidupan masyarakat. Dengan kata lain, proses peningkatan produktivitas kerja dapat dilakukan melalui motivasi, pemberian insentif dan promosi jabatan. Selain itu kemampuan seseorang menyesuaikan perilakunya dengan budaya organisasi mem- punyai relevansi tinggi dengan kemampuan peningkatan produktivitas kerja atau budaya organisasi memiliki dampak positif terhadap perilaku anggotanya berupa kerelaan untuk meningkatkan produktivitas kerjanya (Siagian, 2002).

Segala faktor pendukung dalam menunjang kepuasan kerja karyawan haruslah diperhatikan, sehingga produktivitas kerja karyawan dapat meningkat dalam memajukan perusahaan. Faktor-faktor yang dapat meningkatkan atau mempengaruhi kepuasan kerja karyawan yaitu bisa berupa rangsangan material insentif. Semi material intentif atau non material insentif. Di samping faktor perangsang tersebut kepuasan kerja karyawan bisa juga dipengaruhi oleh faktor manajemen organsiasi yang baik.

Faktor rangsangan berupa material insentif yaitu suatu dorongan atau segala daya perangsang yang dapat dilihat dan dinilai dengan berupa uang secara langsung, misalnya upah, gaji, bonus, uang lebaran dan lain-lain. Adapun semi material intensif yaitu daya perangsang berupa terpenuhinya kebutuhan dari pemberian penghargaan atas prestasi kerja tetapi tidak berupa uang secara langsung misalnya penghargaan bagi karyawan yang berprestasi,hadiah, program promosi dan lainlain. Sementara itu, intensif non material yaitu daya perangsang yang tidak dapat dillihat dan dinilai dengan uang atau materi misalnya kondisi kerja, penempatan karyawan, keamanan, kesehatan dan lain-lain. Faktor lain yaitu berupa manajemen organisasi yang baik yaitu berupa pengaturan, perencanaan yang tepat dari segala lini dan sub organisasi untuk pencapaian tujuan perusahaan yang pada akhirnya menimbulkan kepuasan kerja para karyawan karena segala struktur dan sistem kerja di perusahaan sudah ditetapkan dan dijalankan oleh semua karyawan. Oleh karena itu, dalam melaksanakan pekerjaan para karyawan sudah sesuai dengan tanggung jawabnya atau tidak tumpang tindih.

Suatu alat yang dapat mandorong seseorang untuk berpartisipasi aktif dalam suatu organisasi atau perusahaan, antara lain kesempatan untuk maju. Telah menjadi sifat dasar manusia pada umumnya untuk menjadi lebih baik atau lebih maju dari pada posisi yang demikian pada saat ini. Kesempatan un- 
tuk maju itu dalam suatu organisasi sering disebut sebagai promosi. Suatu promosi berarti pula perpindahan dari suatu jabatan ke jabatan yang lain yang mempunyai status dan tanggung jawab lebih tinggi. Hal ini berarti bawah kompensasi (penerimaan upah/gaji dan sebagainya) menjadi lebih tinggi bila dibandingkan dengan jabatan lama. Perpindahan seseorang pada jabatan baru dapat juga terjadi jika organisasi yang bersangkutan mengalami ekspansi atau karena adanya lowongan yang harus segera diisi. Perwujudan dan prinsip orang yang tepat pada jabatan yang tepat, baik dengan pemindahan atau jalan lain, bukan saja akan membawa hasil yang baik bagi organisasi, tetapi juga kepada petugas yang bersangkutan. Di sinilah pentingnya suatu promosi jabatan, yaitu untuk meningkatkan produktivitas kerja seorang petugas dalam suatu organisasi. Namun, pemberian promosi harus bertitik tolak dari kepentingan organisasi dan bukan kepentingan pribadi seseorang (Samsudin, 2006)

Tujuan penelitian dikemukakan sebagai berikut: (1) untuk mengetahui apakah motivasi, insentif dan promosi jabatan berpengaruh signifikan secara simultan terhadap produktivitas kerja karyawan pada bagian penjualan PT Kapuas Trio Tirta Sari Motor di Kuala Kapuas; (2) untuk mengetahui apakah motivasi, insentif dan promosi jabatan berpengaruh signifikan secara parsial terhadap produktivitas kerja karyawan pada bagian penjualan PT Kapuas Trio Tirta Sari Motor di Kuala Kapuas; dan (3) untuk mengetahui di antara variabel tersebut mana yang lebih dominan pengaruhnya terhadap produktivitas kerja karyawan pada bagian penjualan PT Kapuas Trio Tirta Sari Motor di Kuala Kapuas.

\section{Kajian Literatur}

Menurut Hasibuan (2003:92) Motivasi berasal dari kata latin movere yang berarti dorongan atau daya penggerak. Motivasi ini hanya diberikan kepada manusia, khususnya kepada para bawahan atau pengikut. Motivasi penting karena dengan motivasi ini diharapkan setiap individu karyawan mau bekerja keras dan tinggi. Antusias untuk produktivitas kerja dalam manajemen hanya ditujukan pada sumber daya manusia umumnya dan bawahan pada khususnya motivasi memperso- alkan bagaimana caranya mengarahkan daya dan potensi bawahan, agar mau bekerja sama secara produktif berhasil mencapai dan mewujudkan tujuan yang telah ditentukan. (Hasibuan, 2003:141). Indikator motivasi menurut Hasibuan (2003) yang termasuk motivasi yaitu: (1) kebutuhan fisiologis, (2) kebutuhan rasa aman, (3) kebutuhan sosial, (4) kebutuhan akan penghargaan diri, dan (5) kebutuhan aktualisasi diri.

Menurut Handoko (2002:176), menyatakan bahwa insentif adalah perangsang yang ditawarkan kepada para karyawan untuk melaksanakan kerja sesuai atau lebih tinggi dari standar-standar yang telah ditetapkan. Indikator insentif yaitu: (1) kinerja, (2) kebutuhan, (3) keadilan dan (4) kelayakan.

Menurut Nitisemito (2002:75) Promosi jabatan adalah setiap pemindahan dari satu jabatan kejabatan lain yang lebih tinggi tingkatannya. Indikator promosi jabatan adalah: (1) persyaratan, (2) waktu pelaksaan, (3) pencalonan, dan (4) obyektifitas.

Menurut Ravianto (2005:16) produktivitas kerja adalah setiap hasil yang dicapai dengan peran tenaga kerja persatuan waktu Indikatornya adalah sebagai beikut yaitu: (1) tingkat absensi, dan (2) kualitas dan kuantitas pekerjaan yang dihasilkan.

Kerangka koseptual penelitian ini dapat digambarkan pada Gambar 1.

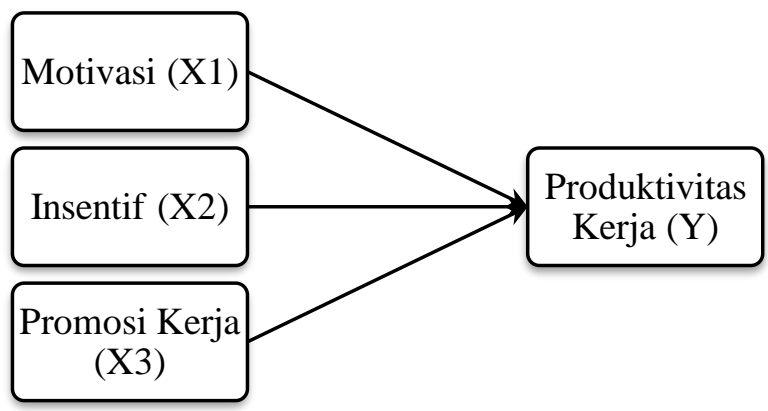

Gambar 1. Kerangka Koseptual Penelitian

Berdasarkan tujuan penelitian dan tinjauan literatur yang telah diuraikan sebelumnya, maka hipotesis dalam penelitian ini sebagai berikut: (1) motivasi, insentif dan promosi jabatan berpengaruh signifikan secara simultan terhadap produktivitas kerja karyawan pada bagian penjualan PT Kapuas Trio Tirta Sari Motor di Kuala Kapuas; (2) motivasi, insentif dan promosi jabatan tidak berpengaruh signifikan secara parsial terhadap 
produktivitas kerja karyawan pada bagian penjualan PT Kapuas Trio Tirta Sari Motor di Kuala Kapuas; dan (3) Karena secara parsial tidak berpengaruh signifikan maka tidak ditemukan variabel yang paling dominan terhadap produktivitas kerja karyawan pada bagian penjualan PT Kapuas Tirta Sari Motor di Kuala Kapuas.

\section{Metode Penelitian}

Populasi yang akan diteliti meliputi seluruh karyawan bagian penjualan PT Kapuas Trio Tirta Sari Motor di Kuala Kapuas yang secara keseluruhan berjumlah 17 orang.

Variabel-variabel yang digunakan dalam penelitian ini perlu diidentifikasi terlebih dahulu agar tidak terdapat perbedaan cara pandang terhadap variabel penelitian. Adapun variabel yang diidentifikasi yaitu: motivasi (X1), insentif (X2), promosi jabatan (X3), dan produktivitas kerja (Y).

Pengukuran data dalam penelitian ini adalah angket atau daftar pertanyaan yang disusun berdasarkan kisi-kisi teoritik dalam bentuk skala Likert. Pertimbangan menggunakan daftar pertanyaan karena pada penelitian survei, penggunaan kuesioner merupakan hal yang pokok untuk mengumpulkan data. Teknik pengumpulan data dalam penelitian ini dilakukan dengan langkah-langkah: (1) observasi, yaitu pengumpulan data dengan mengadakan pengamatan langsung terhadap objek yang diteliti dengan tujuan adalah untuk lebih mengetahui keadaan yang sebenarnya terjadi di lapangan; (2) wawancara langsung dengan responden pada masing-masing bagian, baik wawancara terstruktur maupun tidak terstruktur; (3) kuesioner yang disediakan dengan tujuan untuk mengumpulkan data yang berhubungan dengan variabel yang diteliti yaitu keahlian pegawai dan kinerja pegawai; dan (4) dokumentasi adalah dengan melakukan penelaahan terhadap dokumen yang bernilai seperti monograpi, tugas dan fungsi maupun pustaka yang berkaitan dengan penelitian.

Uji validitas berguna untuk mengetahui apakah ada pertanyaan atau pernyataan pada kuisioner yang harus dihilangkan atau diganti karena dianggap tidak relevan. Uji validitas sering digunakan untuk mengukur ketepatan suatu item dalam kuisioner, apakah item pada kuisioner tersebut sudah tepat dalam mengukur apa yang ingin diukur (Ghozali, 2011: 45). Dalam rangka mengetahui uji validitas, dapat digunakan koefisien korelasi yang nilai signifikannya lebih kecil dari 5\% (level of significance) menunjukkan bahwa pernyataan-pernyataan tersebut sudah sahih/valid sebagai pembentuk indikator.

Uji reliabilitas berguna untuk menetapkan apakah instrumen, dalam hal ini kuesioner, dapat digunakan lebih dari satu kali, paling tidak boleh responden yang sama. Uji reliabilitas untuk alternatif jawaban lebih dari dua menggunakan uji Cronbach's Alpha, yang nilainya akan dibandingkan dengan nilai koefisien reliabilitas minimal yang dapat diterima. Jika nilai nilai Cronbach's Alpha > 0.6 , maka instrumen penelitian reliabel. Jika nilai Cronbach's Alpha < 0.6, maka instrumen penelitian tidak reliabel (Ghozali, 2011: 133).

Uji asumsi klasik dilakukan untuk mengetahui apakah parameter yang dihasilkan bersifat BLUE (Best Linier Unbiased Estimation), artinya koefisien regresi pada persamaan tersebut tidak terjadi penyimpangan-penyimpangan yang berarti.

Asumsi normalitas digunakan untuk menguji apakah data berdistribusi normal atau tidak. Data yang baik adalah yang berdistribusi normal. Uji normalitas bertujuan untuk menguji apakah dalam sebuah model regresi, variabel dependen, variabel independen atau keduanya mempunyai distribusi normal atau tidak (Ghozali, 2011). Pengujian normalitas dalam penelitian ini dilakukan dengan menggunakan uji statistik KolmogorovSmirnov. Level of significant yang digunakan adalah 0,05. Data berdistribusi normal jika nilai Asymp. Sig. (2tailed) hasil perhitungan dalam komputer lebih dari 0,05.

Uji Multikolinearitas bertujuan untuk menguji apakah model regresi ditemukan adanya korelasi antar variabel independen. Multikolonearitas adalah situasi adanya variabel-variabel bebas diantara satu sama lain. Model regresi yang baik seharusnya tidak terjadi korelasi di antara variabel independen. Proteksinya dilakukan dengan menggunakan tolerance value dan VIF (variance inflation factor). Jika nilai-nilai tolerance value $<0,1$ 
dan nilai VIF > 10, maka terjadi multikolinieritas.

Uji heteroskedastisitas bertujuan menguji apakah dalam model regresi terjadi ketidaksamaan variance dari residual satu pengamatan ke pengamatan yang lain. Model regresi yang baik adalah yang tidak terjadi heteroskedastisitas di mana variance residual satu pengamatan ke pengamatan lain tetap. Ada beberapa cara untuk menguji heteroskedastisitas dalam variance error terms untuk model regresi. Dalam penelitian ini akan digunakan metode chart (diagram scatterplot) dengan dasar analisis yaitu: (1) jika ada pola tertentu, seperti titik-titik yang ada membentuk pola tertentu yang teratur (bergelombang, melebar, kemudian menyempit), maka mengindikasikan telah terjadi heteroskedastisitas; dan (2) jika ada pola yang jelas, serta titiktitik menyebar di atas dan di bawah angka 0 dan pada sumbu Y, maka tidak terjadi heteroskedastisitas.

\section{Hasil Penelitian dan Pembahasan}

Instrumen yang valid berarti alat ukur yang digunakan untuk mendapatkan data (mengukur) itu valid. Alat ukur motivasi, insentif, dan promosi jabatan terhadap produktivitas kerja karyawan pada bagian penjualan PT Kapuas Trio Tirta Sari Motor di Kuala Kapuas.

Berdasarkan uji validitas yang diterapkan pada 17 orang karyawan pada bagian penjualan PT Kapuas Trio Tirta Sari Motor di Kuala Kapuas diketahui bahwa angket motivasi, insentif, promosi jabatan dan produktivitas kerja. Diketahui dari semua pertanyaan dinyatakan valid yang berarti juga tidak terdapat pertanyaan yang tidak valid/ gugur.

Setelah diketahui jumlah item yang valid selanjutnya dilakukan uji reliabilitas instrumen yang berorientasi pada satu pengertian bahwa kuesioner yang digunakan dalam penelitian ini dapat dipercaya untuk digunakan sebagai alat pengumpul data, uji reliabilitas sendiri menggunakan koefesien Cronbach Alpha. Suatu angket dikatakan reliabel jika nilai $r$ alpha yang dihasilkan dalah positif. Hasil uji reliabilitas dapat dilihat pada Tabel 1.
Tabel 1. Hasil Uji Reliabilitas

\begin{tabular}{lc}
\hline \multicolumn{1}{c}{ Variabel } & Koefisien Cronbach \\
\hline Motivasi & 0,694 \\
\hline Insentif & 0,894 \\
\hline Promosi Jabatan & 0,838 \\
\hline Produktivitas Kerja & 0,904 \\
\hline
\end{tabular}

Variabel motivasi mempunyai $\mathrm{r}$ alpha sebesar 0,694, insentif mempunyai $r$ alpha sebesar 0,894 , promosi jabatan mempunyai $r$ alpha sebesar 0,838, dan produktivitas kerja mempunyai $r$ alpha sebesar 0,904. Dari keempat nilai $r$ alpha yang dihasilkan bernilai positif dan lebih besar dari $\mathrm{r}$ tabel $(\mathrm{r}$ tabel $=$ 0,4444 ) yang berarti keseluruhan instrumen penelitian ini handal dan dapat digunakan sebagai alat ukur dalam penelitian ini. Berdasarkan hasil uji validitas dan reliabilitas yang dilaksanakan semua item yang tidak valid/ gugur tidak akan digunakan sebagai alat ukur dalam penlitian ini. Dari keempat nilai $r$ alpha yang dihasilkan bernilai positif yang berarti keseluruhan instrumen penelitian ini handal dan dapat digunakan sebagai alat ukur dalam penelitian ini. Berdasarkan hasil uji validitas dan reliabilitas yang dilaksanakan semua item yang tidak valid/gugur tidak akan digunakan sebagai alat ukur dalam penelitian ini.

Berdasarkan uji normalitas dengan Kolmogorov-Smirnov Test diperoleh nilai KSZ sebesar 0,555 dan Asymp Sig 0,917 lebih besar dari 0,05 maka dapat disimpulkan data berdistribusi normal.

Tabel 2. One-Sample Kolmogorov-Smirnov Test Unstandardized Residual

\begin{tabular}{llr}
\hline $\mathrm{N}$ & & 17 \\
\multirow{2}{*}{$\begin{array}{l}\text { Normal } \\
\text { Parameters }\end{array}$} & Mean &, 0000000 \\
\cline { 2 - 3 } & Std. &, 23844334 \\
Most Extreme & Deviation & \\
\cline { 2 - 3 } Differences & Absolute &, 135 \\
\cline { 2 - 3 } & Positive &, 135 \\
\cline { 2 - 3 } Kolmogorov-Smirnov Z &, 082 \\
\hline \multicolumn{2}{l}{ Asymp. Sig. (2-tailed) } &, 555 \\
\hline
\end{tabular}

a. Test distribution is Normal.

b. Calculated from data.

Hasil uji multikolinearitas menunjukkan nilai tolerance semua variabel indepen- 
den lebih kecil dari 0,10 dan Nilai VIF semua variabel independen lebih besar dari 10,00. Berdasarkan nilai tersebut dapat disimpulkan bahwa terjadi multikolinearitas.

Hasil uji heteroskedastisitas dapat dilihat pada Gambar 2 di mana terlihat titik-titik menyebar dan tidak membentuk pola tertentu yang jelas. Jadi, dapat disimpulkan bahwa tidak terjadi masalah heterokedastisitas.

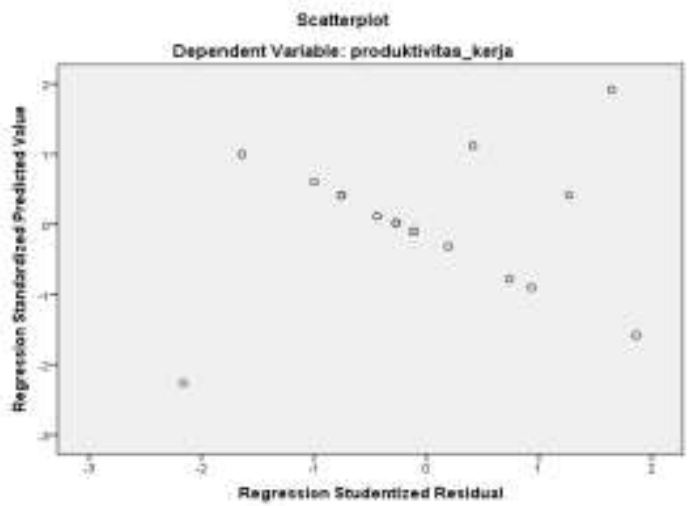

Gambar 2. Grafik Scatterplot

Dari Tabel 3 terlihat nilai $\mathrm{R}$ square sebesar 0,627 . Hal ini berarti $62,7 \%$ model penelitian mampu menjelaskan dari perubahan produktivitas kinerja, $(100 \%-62,7 \%=37,3$ $\%)$. Standart error of estimate adalah 0,265.

Dari uji Anova atau F test, didapat F hitung adalah 7,295 dengan tingkat signifikansi 0,004. Karena probabilitas 0,004 jauh lebih kecil dari 0,005 maka model regresi bisa dipakai dan secara simultan signifikan, karena nilai sig nya $<0,005$.

Berdasarkan tabel 4 , persamaan regresi sebagai berikut:

$Y=1,862+-0,186 X 1+0,885 X 2+-0,118 X 3$

Peneliti menyimpulkan bahwa: (1) konstanta 1,862 ; (2) koefisien regresi $X_{1} B$ sebesar -0,186; (3) koefisien regresi $\mathrm{X}_{2} \mathrm{~B}$ sebesar 0,885; dan (4) koefisien regresi $\mathrm{X}_{3} \mathrm{~B}$ sebesar $-0,118$.

Uji t menguji signifikansi konstanta dan variabel dependen terlihat nilai sig $\mathrm{X}_{1}$ sebesar 0,752, nilai sig $\mathrm{X}_{2}$ sebesar 0,110 dan nilai sig $X_{3}$ sebesar 0,638. Maka dari hasil pengujian uji t dapat dikatakan koefisien regresi $\mathrm{X}_{1}, \mathrm{X}_{2}$ dan $\mathrm{X}_{3}$ tidak berpengaruh signifikan karena nilai lebih besar dari 0,005.

Tabel 3. Model Summary ${ }^{b}$

\begin{tabular}{lcccc}
\hline Model & R & R Square & Adjusted R Square & Std. Error of the Estimate \\
\hline 1 &, $792^{\mathrm{a}}$ &, 627 &, 541 &, 265
\end{tabular}

a. Predictors: (Constant), promosi_jabatan, motivasi, insentif

Tabel 4. ANOVA ${ }^{\mathrm{a}}$

\begin{tabular}{c|lccccc}
\hline \multicolumn{1}{c}{ Model } & Sum of Squares & Df & Mean Square & F & Sig. \\
\hline \multirow{2}{*}{1} & Regression & 1,531 & 3 &, 510 & $7,295,004^{\mathrm{b}}$ \\
\cline { 2 - 7 } & Residual &, 910 & 13 &, 070 & & \\
\cline { 2 - 7 } & Total & 2,441 & 16 & & & \\
\hline \multirow{2}{*}{} & & Depil & &
\end{tabular}

a. Dependent Variable: produktivitas_kerja

b. Predictors: (Constant), promosi_jabatan, motivasi, insentif

Tabel 5. Coefficients ${ }^{\mathrm{a}}$

\begin{tabular}{lcccccc}
\hline \multirow{2}{*}{ Model } & \multicolumn{2}{c}{ Unstandardized Coefficients } & Standardized Coefficients & \multirow{2}{*}{ t } & Sig. \\
\cline { 2 - 5 } & $\mathrm{B}$ & Std. Error & Beta & & \\
\hline (Constant) & 1,862 &, 811 & &,- 198 & 2,297 &, 039 \\
\hline Motivasi &,- 186 &, 578 &,- 322 &, 752 \\
\hline Insentif &, 855 &, 499 & 1,080 & 1,715 &, 110 \\
\hline promosi_jabatan &,- 118 &, 245 &,- 133 &,- 482 &, 638 \\
\hline
\end{tabular}

a. Dependent Variable: produktivitas_kerja 


\section{Kesimpulan}

Berdasarkan hasil analisis yang dilakukan dalam penelitian ini, beberapa kesimpulan yang dapat diambil adalah: (1) motivasi, insentif dan promosi jabatan berpengaruh signifikan secara simultan terhadap produktivitas kerja karyawan pada bagian penjualan PT Kapuas Tirta Sari Motor di Kuala Kapuas; (2) motivasi, insentif dan promosi jabatan tidak berpengaruh signifikan secara parsial terhadap produktivitas kerja karyawan pada bagian penjualan PT Kapuas Tirta Sari Motor di Kuala Kapuas; dan (3) karena secara parsial tidak berpengaruh signifikan maka tidak ditemukan variabel yang paling dominan terhadap produktivitas kerja karyawan pada bagian penjualan PT Kapuas Tirta Sari Motor di Kuala Kapuas.

Adapun saran yang penulis bisa disampaikan untuk PT Kapuas Tirta Sari Motor di Kuala Kapuas khususnya karyawan pada bagian penjualan melalui penelitian ini adalah: (1) motivasi, insentif dan promosi jabatan di bagian penjualan PT Kapuas Tirta Sari Motor di Kuala Kapuas sebagai alat bantu dalam proses; (2) menjadikan motivasi, insentif dan promosi jabatan untuk meningkatkan produktivitas kerja yang ada di lingkungan bagian penjualan PT Kapuas Tirta Sari Motor di Kuala Kapuas; dan (3) melanjutkan penelitian untuk mengetahui fak- tor-faktor lain yang berpengaruh lebih dalam meningkatkan produktivitas bagian penjualan PT Kapuas Trio Tirta Sari Motor di Kuala Kapuas.

\section{DAFTAR PUSTAKA}

Ghozali Imam, 2011:, Aplikasi Analisis Multivariate dengan Program SPSS. Universitas Dipenogoro, Semarang.

Handoko Martini, 2000 Motivasi Penggerak Tingkah Laku, Cetakan Ketiga, Kanisius(Anggota IKAPI), Yogyakarta Handoko, T, Hani, 2000, Manajemen, Edisi Kedua, Cetakan Ketigabelas, BPFE, Yogyakarta.

Hasibuan Malayu S.P., 2003 Manajemen Sumber Daya Manusia, Edisi Revisi, Cetakan Kelima, Bumi Aksara, Jakarta.

Nitisemito Alex S., 2002, Manajemen Personalia : Manajemn Sumber Daya Manusia, Edisi Ketiga, Cetakan Kesembilanbelas, Ghalia Indonesia, Jakarta.

Ravianto J., 2005, Produktivitas dan Manusia Indonesia, SIUPP, Jakarta.

Samsudin, Sadili, 2006, Manajemen Sumber daya Manusia, Cetakan Ke-1, Pustaka Setia, Bandung.

Siagian Sondang P., 2002, Manajemen Sumber Daya Manusia, Bumi Aksara, Jakarta. 